\title{
LINKING GEOLOGY AND GEOTECHNICAL ENGINEERING IN KARST: THE QATAR GEOLOGIC MAPPING PROJECT
}

\author{
Randall C. Orndorff \\ U.S. Geological Survey, 12201 Sunrise Valley Drive, Reston, Virginia, 20192, USA, rorndorf@usgs.gov
}

Michael A. Knight

Gannett Fleming, Inc., P.O. Box 67100, Harrisburg, Pennsylvania, 17106, USA, mknight@gfnet.com

Joseph T. Krupansky

Gannett Fleming, Inc., 1010 Adams Avenue, Audubon, Pennsylvania, 19403, USA, jkrupansky@gfnet.com

Khaled M. Al-Akhras

Ministry of Municipality and Environment,Doha, Qatar, kalakhras@mme.gov.qa

Robert G. Stamm

U.S. Geological Survey, 12201 Sunrise Valley Drive, Reston, Virginia, 20192,USA, rstamm@usgs.gov

Umi Salmah Abdul Samad

Ministry of Municipality and Environment, Doha, Qatar, umi@mme.gov.qa

Elalim Ahmed

Ministry of Municipality and Environment, Doha, Qatar, umi@mme.gov.qa

\begin{abstract}
During a time of expanding population and aging urban infrastructure, it is critical to have accurate geotechnical and geological information to enable adequate design and make appropriate provisions for construction. This is especially important in karst terrains that are prone to sinkhole hazards and groundwater quantity and quality issues. The State of Qatar in the Middle East, a country underlain by carbonate and evaporite rocks and having abundant karst features, has recognized the significance of reliable and accurate geological and geotechnical information and has undertaken a project to develop a robust geotechnical relational database and prepare geologic and thematic digital maps. These products will support planning, design, and decision-making processes related to urban infrastructure development in the rapidly growing State and be particularly useful in the early stages of geotechnical investigations. The U.S. Geological Survey (USGS), Gannett Fleming, Inc., and the Qatar Ministry of Municipality and Environment (MME) have partnered to design a geologic mapping project that will merge geological and geotechnical information to develop a framework to model the geology, karst, and resources important to support growth in the State. The Qatar Geologic Mapping Project (QGMP) has a mission to integrate sound geoscience data for the State of Qatar to address societal, environmental and educational needs that include water and mineral resources management and natural hazards reduction.
\end{abstract}

\section{Introduction}

Currently, the State of Qatar does not have adequate geologic maps at regional and local scales with detailed descriptions, proper base maps, GIS, and digital geodatabases to adequately support future development. To better understand the region's geological and geotechnical conditions influencing long term sustainability of future development, the Infrastructure Planning Department (IPD) of the Ministry of Municipality and Environment (MME) of the State of Qatar has commenced the Qatar Geologic Mapping Project (QGMP). This project will develop high-quality geologic maps, geotechnical data, and thematic maps important in meeting this objective, which includes understanding the State's karst environment and characteristics through development of a geologic framework.

Qatar, located in the Middle East, is a peninsula surrounded on three sides by the Arabian Gulf (Figure 1). Although it has an arid climate with average annual precipitation of $7.5 \mathrm{~cm}$, its karst topography is well developed with more than 9700 depressions identified in a country of $11,586 \mathrm{~km}_{2}$ (U.S. Central Intelligence Agency, 2017). Large open throat and collapse sinkholes, and caves are found in rural and urban areas. Although Qatar is a desert environment, karst that formed during a wetter climate in the Pleistocene impacts the State today as developers often encounter cavities in the subsurface 


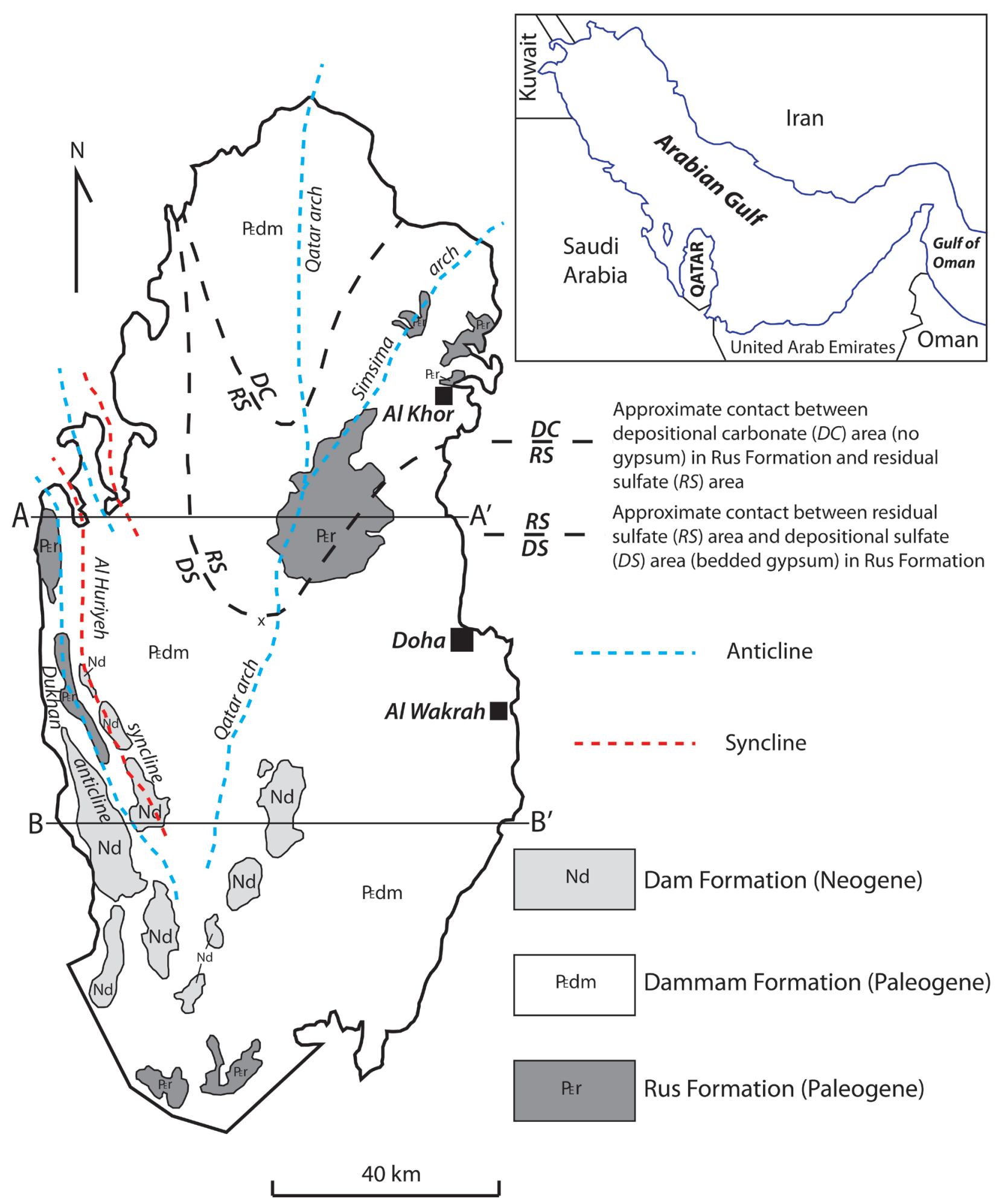

Figure 1. Simplified geologic map of Qatar showing facies types of the Rus Formation and differences in karst development (modified from Eccleston et al., 1981). Schematic sections A-A' and $B-B^{\prime}$ are shown on figure 2 . 
during construction activities. One of the essential objectives of the QGMP is to analyze the geologic controls on karst development, particularly in terms of lithology, groundwater, regional structures, and fractures by utilizing geologic field mapping, subsurface information, and remote sensing data. Development of high-quality geologic and thematic maps coupled with a robust geotechnical relational database will provide planners, developers and designers the scientific basis to make informed decisions with respect to the potential physical and financial risks associated with future land use and development.

\section{Geologic Setting}

The low relief of the Qatar peninsula is coincident with a broad, north-trending fold called the Qatar arch with the axis of the arch being nearly equidistant from east and west coastlines (Figures 1 and 2). Along the western margin of the peninsula is the Dukhan anticline, a structure that defines Qatar's largest onshore oil field (Figures 1 and 2). Approximately 80 percent of the land surface exposes chalky dolostone and limestone of the Eocene Dammam Formation (Figure 1). In southern Qatar, the Dammam is disconformably overlain by $40-80 \mathrm{~m}$ of limestone, dolostone, and evaporite rocks of the Miocene Dam Formation. The Dam Formation commonly occurs as erosional remnants that cap the higher elevations.

Qatar has been part of a stable platform from the Permian through part of the Tertiary as recognized by the cycles of shallow water carbonate rocks with some anhydrite, gypsum and clay deposits (Perotti et al., 2011).
The surface and near subsurface stratigraphy includes as much as $600 \mathrm{~m}$ of Tertiary carbonate and evaporite rocks with some interbedded clastic units (Figure 3). Within the limestone and dolostone exposures of the Eocene Dammam Formation, the Umm Bab Member is an important unit to structural engineers based on its common use as a load-bearing stratum, however it also exhibits a proclivity to air- and water-filled cavities, and thus, is the focus of considerable geotechnical investigation. The base of the Dammam consists of clay or shaley to clayey dolomitic limestone called the Midra Member. In southern and central Qatar, this member can be considered an aquitard where it is sufficiently thick and mostly clay; it is absent in the northern part of Qatar. The underlying Eocene Rus Formation also demonstrates lithologic changes between the northern and southern parts of the State (Figure 1). Thick sequences of gypsum in the lower part of the Rus Formation are present in the south, but not in the north where both depositional conditions and secondary dissolution may explain its absence (Eccleston et al., 1981). The Paleocene and lower Eocene Umm er Radhuma Formation is a complex, poorly understood unit that only occurs in the subsurface of Qatar. Due to its secondary and tertiary porosity, the Umm er Radhuma Formation is an important unit for injection of treated sewage effluent and waste fluid disposal in oil and gas production areas. Also, the unit is under evaluation for use in regional aquifer storage and recovery programs.

\section{Robust Geologic Map Products}

The wide variety of uses of geologic maps is so broad that they are one of the most requested scientific products whose return on investment have been calculated at more than 25 times their cost to produce (Bhagwat and

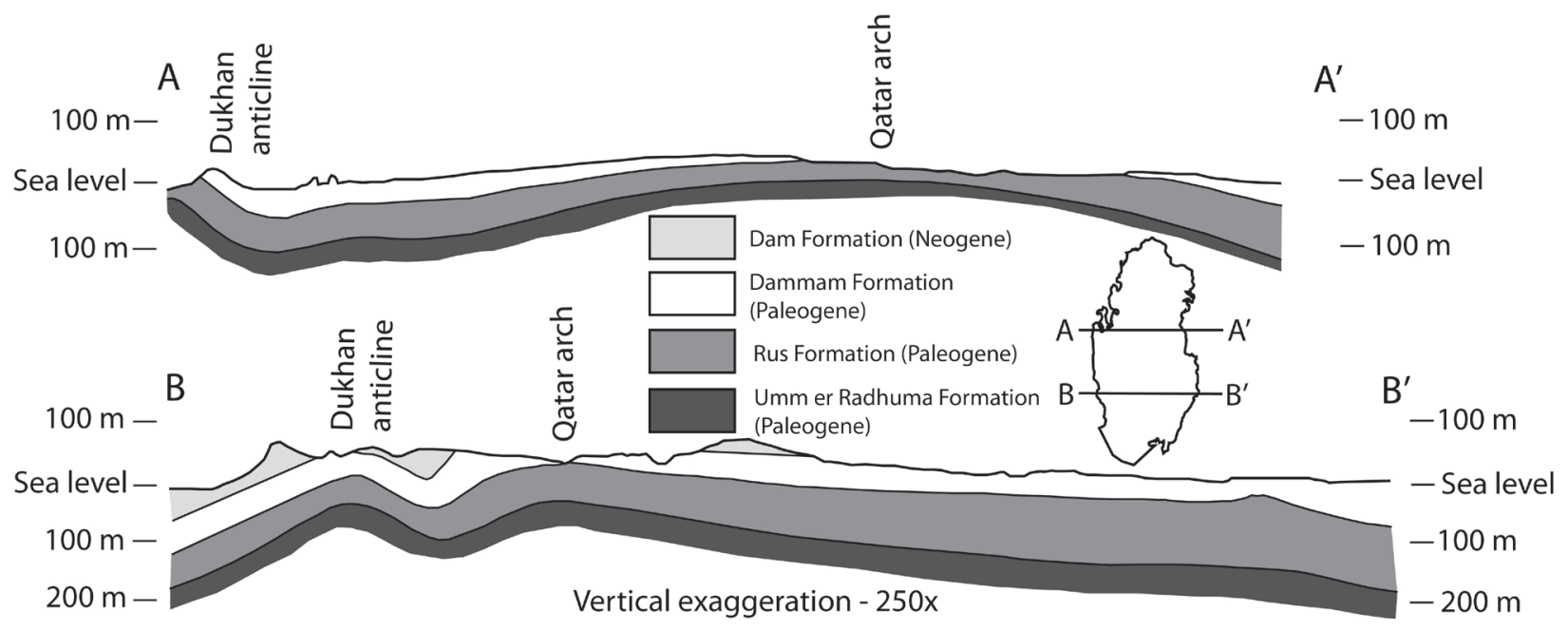

Figure 2. Schematic geologic cross sections of Qatar (modified from Seltrust Engineering Ltd., 1980). Lines shown on figure 1. 

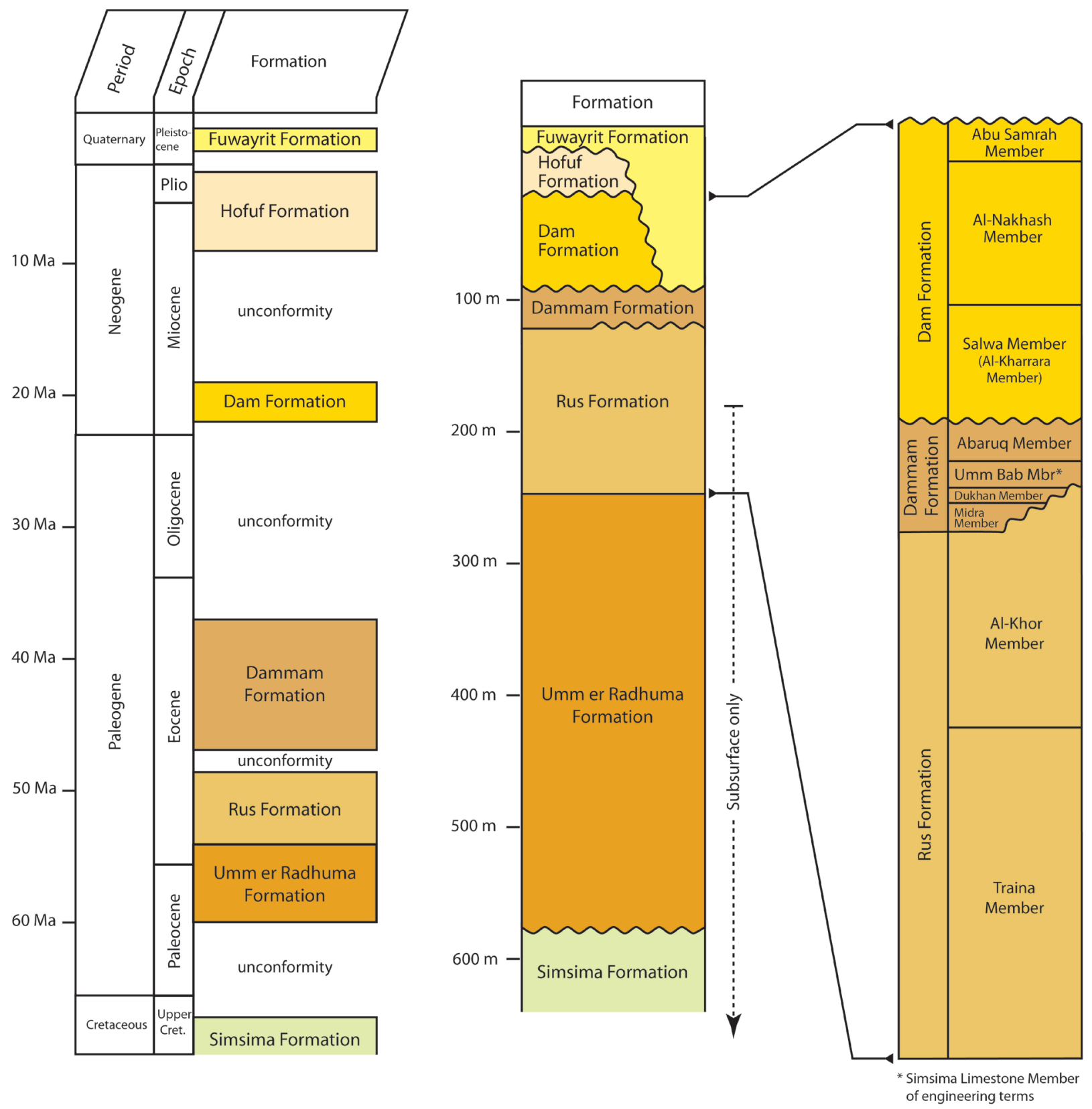

Figure 3. Stratigraphic column for the Qatar Geologic Mapping Project including age and thickness of uppermost Cretaceous and Cenozoic units in Qatar. Sources include Al-Husseini (2008), Al-Saad and Ibrahim (2002), Al-Saad (2005), Dill et al. (2003), Dill et al. (2005), Dill and HenjesKunst (2007), Haq and Al-Qahtani (2005), Kok and LeBlanc (2012), LeBlanc (2008), Sharland et al. (2004), Williams and Walkden (2002).

Ipe, 2000a; Bhagwat and Ipe, 2000b). The benefits of a geologic map include increased credibility of projects and time saved in completing projects. The robustness of a geologic map is found in its multiple uses. For example, a geologic map produced to address mineral and energy resources of a region can be used by other investigators to evaluate groundwater resources. Therefore, geologic maps tailored to geotechnical and other development issues will continue to provide useful information to address future needs.

The MME has undertaken the development of a geotechnical relational database to compile and preserve existing subsurface information, and to provide a structure for future updates. This investment in engineering and science is now actively used to assess 
conditions in and around on-going infrastructure and development projects. In addition, the database serves as a substantial information source for producing geologic maps and 3D frameworks, structure contour maps, and isopach maps. The geotechnical attributes contained in the database provide detail for the many engineering investigations being completed in Qatar, and they add geotechnical information to descriptions of map units that are important to the geologic mapping effort. Ultimately, the desired GIS-based digital geologic map for the State of Qatar will be a data schema backed by a geodatabase that can support development of a diverse and utilitarian suite of thematic maps.

Evaluation of karst characteristics and impacts on development in Qatar requires detailed geologic products:

- Geologic map of the entire State of Qatar at 1:100,000 scale

- Regional and local geologic maps at 1:50,000 and 1:20,000 scales

- Thematic maps related to specific geological properties and geotechnical characteristics

- A Geotechnical Cavity Collapse Model based on detailed analysis of geological, hydrogeological, and geotechnical factors influencing failure/stability of subsurface cavities

- A 3D geological model for the Doha Metropoli$\tan$ Area

\section{Karst Characterization}

With carbonate and evaporite rocks at and near the surface, Qatar exhibits widespread karst features characterized by sinkholes, shallow closed depressions, and caves. Active karst regions are usually associated with humid climate regimes where precipitation and organics in soils create carbonic acid that over time dissolves carbonate and evaporate rocks at and below the surface. By contrast, Qatar currently lacks both abundant precipitation and a well-developed soil profile containing organic material, strongly suggesting that karst initiation occurred in the geologic past. Previous investigators concluded that karst in Qatar developed in the past during a time of a wet climate 560,000 to 325,000 yrs ago (Sadiq and Nasir, 2002). Several prominent karst features, including large sinkholes and caves (Figure 4), are natural laboratories to understand past conditions.

Embabi and Ali (1990) report more than 9,700 depressions in Qatar that range from a hundred meters to about $3 \mathrm{~km}$ in width and between a few centimeters to $25 \mathrm{~m}$ in depth. They identified the following types of depressions:

- Sinkholes developed by collapse or subsidence, generally circular

- Shallow depressions with a single center

- Compound depressions, which are an amalgamation of depressions with overall closed drainage (Sadiq and Nasir, 2002)

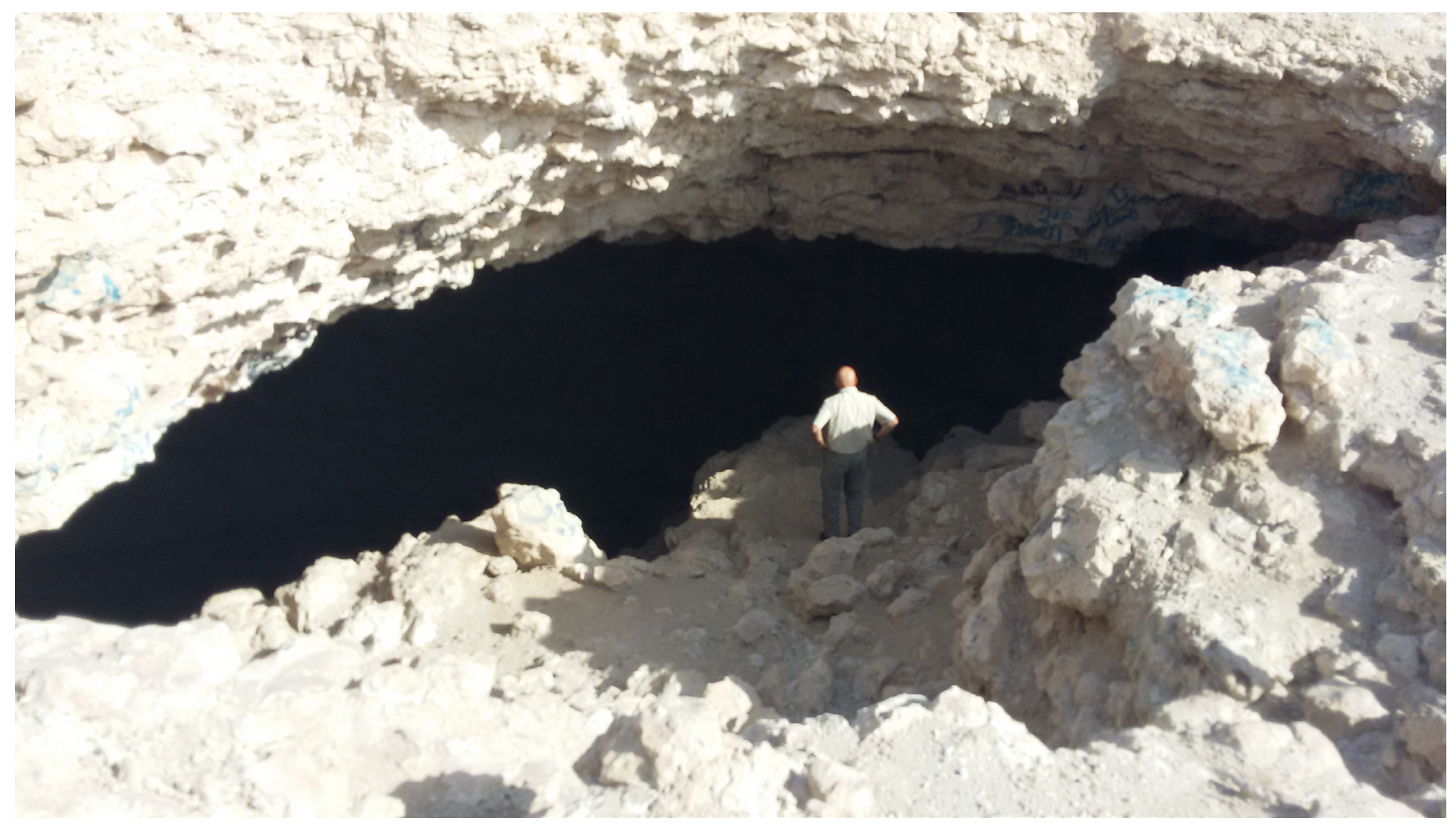

Figure 4. Misfir sinkhole and cave in central Qatar. 
Duggan (2014) demonstrated that the number and size of depressions or closed drainages is sensitive to the mapping method. His study developed GIS work flows to identify depressions with large drainage basins that were most likely to be associated with collapse. The size and depth of depressions correlated directly with the presence or absence of gypsum layers in the Rus Formation (Figure 1). Larger depressions were found in areas where gypsum in the Rus Formation was likely to have dissolved.

The relationship of various geologic and hydrologic parameters to the spatial distribution of karst features aid in determining controls on the various morphologies and density of features (Orndorff et al., 2000; Weary and Orndorff, 2002). These include stratigraphic, lithologic, structural, topographic, and hydrogeologic controls. Previous remote sensing techniques used to identify depressions and sinkholes in Qatar used Landsat satellite imagery or air photo analysis. More recently, the use of high resolution digital elevation models generated from LiDAR has greatly improved identification of controls on karst processes by producing a more comprehensive spatial distribution and database of karst.

For the current study in Qatar, LiDAR data collected in 2017, new topographic maps, and sub-half meter satellite imagery provide multiple geospatial data sets to assess geomorphic features associated with karst and their potential relationship to geologic structures. This data will be processed utilizing appropriate GIS-based algorithms of Doctor and Young (2013) and Duggan, (2014) to delineate closed depression and then evaluated to determine if they are of karst origin.

Through detailed geologic mapping and high resolution digital elevation models from LiDAR, future karst studies will build onto Duggan's (2014) work. For example, high resolution terrain models may lead to an increase in mapped sinkholes. With accurate delineation of karst features such as sinkholes and caves, an understanding of geologic (i.e., structure and stratigraphy) and hydrologic (e.g. relationship to wadis and depth to water table) controls can be determined. Since the Rus Formation plays a major stratigraphic role in both past and current karst processes, mainly in the south, data from outcrops and the subsurface will be built into a southward migrating anhydrite dissolution model following the work of Eccleston et al. (1981). More information on karst related to deeper systems can be gleaned from studying facies changes in the Umm er Radhuma and Dammam Formations in concert with facies models for the Rus Formation. The Dammam Formation is of interest for geotechnical engineering, and the Umm er Radhuma has critical karst zones that continue offshore and are used for waste disposal (Zampetti et al., 2014). Mapping facies changes of the Umm er Radhuma can help determine if its varying lithologies can serve mixed use of waste disposal and aquifer storage.

\section{Karst Hazards}

Karst features pose a potential hazard that need to be considered for land-use planning, construction, and groundwater resource management. Sinkholes, collapses, and caves/cavities present a hazard for construction, potentially impacting the load-bearing capacity of the rock. Deep-seated sinkholes with connections to deep conduits provide a point source for surface and nearsurface contamination that can impact aquifers. By adding karst features to a GIS-based geospatial project, this information can be used with geologic maps to better define geologic controls associated with, (1) karst-related potential sources of groundwater contamination, (2) collapse features that affect transportation infrastructure, and (3) karst features that may potentially impact future development in urban areas.

In addition to the geotechnical rock mass characteristics of subsurface materials, particularly with respect to building foundation design and buried infrastructure, owners, engineers, developers, and planners are also very interested in understanding the behavior of karst features and the potential geological hazards they may cause. With carbonate and evaporite rocks at and near the surface, cavity collapse and settlement associated with the presence of shallow solution cavities cause significant geotechnical and other engineering problems across the entire State of Qatar. The Rus and Dammam Formations, which are composed of interlayered limestone, dolostone, mudstone, siltstone, and gypsum, underlie the majority of the State including the developing urban corridor between Al Khor and Al Wakrah (Figure 1). The geologic framework is used to define and understand the following:

- Types of karst features present

- Density of karst features

- Catchment areas of depressions

- Geologic controls on karst formation (structure and stratigraphy)

Although Qatar is a mature karst terrain with more than 9,700 large and small depressions (Sadiq and Nasir, 2002), few published karst studies exist. Duggan (2014) delimited three geographical areas of depressions with differing characteristics - a northern, central, and southern area, which individually are associated with Eccleston et al.'s (1981) model of deposition and gypsum dissolution in the Rus Formation (DC, RS and 
DS on Figure 1). The northern area (DC) is associated with depositional carbonate (no gypsum) with shallow, low-lying irregular-shaped depressions (Figure 1). The central area (RS) is associated with residual sulfate (residual gypsum) with elongate depressions, and a southern depositional sulfate area (DS) (bedded gypsum) with deep circular depressions. The southern area is associated with bedded gypsum and appears to cause collapse sinkholes as intrastratal karst. Many known caves are located along or near the crest of the Qatar arch suggesting structural control on karst development (Sadiq and Nasir, 2002). Sadiq and Nasir (2002) noted that most karst features are oriented northeast-southwest and northwest-southeast. These orientations are similar to the trends of regional fracture traces, providing strong evidence of fracture or structural control on karst. Since the modern arid environment is generally not conducive to major karst development, it is suspected that much of the carbonate dissolution occurred in the past. Sadiq and Nasir (2002) reported that the middle Pleistocene was one of these humid periods. Current collapse potential is believed to be tied to dissolution of gypsum in the Rus Formation in central and southern Qatar (Eccleston et al., 1981).

Of concern to the MME is the impact of karst on existing infrastructure and development projects. The following have been observed:

- Settling of foundations due to intrastratal dissolution

- Subsurface erosion of soil into fractures and conduits by flowing groundwater

- Collapse of the land surface

- Rapid inundation of groundwater into construction sites

In urban areas, the shallow aquifers are highly affected by the dewatering associated with the enormous construction projects. This leads to changes to the water table that may lead to the development of karst features. In February 2015, a tunnel boring machine (TBM) working near a light-rail station as part of the Qatar Rail Doha Project was damaged when an unexpected incursion of saline water flooded into and inundated the underground excavation of one of the twin Red Line tunnels during pilot boring advancement (MME, personal communication). No human injuries were suffered in this incident but the 7-meter diameter TBM was heavily damaged requiring extensive repair. Geotechnical investigations preceding the TBM work, which included numerous shallow bore holes, did not detect the ground conditions indicative of conduit flow of saline water. However, north of this location, the Dahl Al Hamam sinkhole was reported to have a tidal interconnection and is approximately $4.5 \mathrm{~km}$ from the coastline (Howari et al., 2016).

Rising groundwater levels have been noticed in various urban areas in Qatar due to infiltrations from public water supply lines, reticulated wastewater collection systems, septic tanks, drainage networks, and irrigation water. However, state-wide, the limited natural renewable groundwater resource is proving to be insufficient to supply the increasingly high rates of water consumption with population growth. The State of Qatar is heavily investing in groundwater management studies to develop strategies for water security and in infrastructure to build resiliency.

\section{Future Karst Studies}

By tailoring geologic maps of karst areas with geotechnical rock properties and collaborating with the professionals who use the maps, a more comprehensive, robust geologic map can be produced to aid in planning infrastructure projects. Production of digital geologic maps at detailed scales will support the QGMP mission of integrating sound geoscience data for the State of Qatar to societal and environmental needs, which include water and mineral resources management and natural hazards reduction.

There are many potential karst studies that can be undertaken for the State of Qatar. However, to address the current needs related to the QGMP, the following actions and deliverables are envisioned as part of this project.

- Map and study sinkhole caves to determine controls on cave and conduit development

- Digitally map closed depressions utilizing appropriate geospatial tools and algorithms on LiDAR-derived digital elevation model

- Build upon Duggan (2014) work on mapping and predicting sinkholes

- Classify depressions based on geologic, topographic, and hydrologic controls

- Determine geologic and hydrogeologic controls on karst development

- Attempt to date cave formation (i.e., OSL and paleomagnetism)

- Compare cave passage orientations, sinkhole distribution, and other karst features with fracture, lineament, and discontinuity trends, structural geology, stratigraphy, and potentiometric surfaces to determine controls on karst development

- Include karst features on geologic maps, and in GIS and geodatabase 
- Produce lithofacies maps of Rus Formation and compare to karst zones

- Develop gypsum karst model of the Rus Formation using previous and new data on the stratigraphy, and the presence and absence of gypsum from north to south (no gypsum, residual gypsum, bedded gypsum zones)

- Develop a country-wide hydrogeological model to better understand the rapid changes in groundwater and its impact on forming new cavities

\section{References}

Al-Husseini MI. 2008. Middle East Geologic Timescale; Cenozoic Era, Cretaceous and Jurassic Periods of Mesozoic Era. Gulf PetroLink, GeoArabia 13 (4). Large-format chart.

Al-Saad H, Ibrahim MI. 2002. Stratigraphy, micropaleontology, and paleoecology of the Miocene Dam Formation, Qatar. Gulf PetroLink, GeoArabia 7 (1): 9-28.

Al-Saad H. 2005. Lithostratigraphy of the Middle Eocene Dammam Formation in Qatar, Arabian Gulf: effects of sea-level fluctuations along a tidal environment. Journal of Asian Earth Sciences 25: 781-789.

Bhagwat SB, Ipe VC. 2000a. Economic benefits of detailed geologic mapping to Kentucky. Illinois State Geological Survey Special Report 3: 30.

Bhagwat SB, Ipe VC. 2000b. What are geologic maps worth. Geotimes, December 2000: 36-37.

Dill HG, Nasir S, Al-Saad H. 2003. Lithological and structural evolution of the northern sector of Dukhan anticline, Qatar, during the early Tertiary: with special reference to sequence stratigraphic bounding surfaces. Gulf PetroLink, GeoArabia 8 (2): 201-226.

Dill HG, Botz R, Berner Z, Stuben D, Nasir S, Al-Saad H. 2005. Sedimentary facies, mineralogy, and geochemistry of the sulphate-bearing Miocene Dam Formation in Qatar. Sedimentary Geology 174 (1-2): 63-96.

Dill HG, Henjes-Kunst F. 2007. Strontium (87Sr/86Sr) and calcium isotope ratios $(44 \mathrm{Ca} / 40 \mathrm{Ca}-$ $44 \mathrm{Ca} / 42 \mathrm{Ca})$ of the Miocene Dam Formation in Qatar: tools for stratigraphic correlation and environment analysis. Gulf PetroLink, GeoArabia 12 (3): 61-76.

Doctor DH, Young JA. 2013. An evaluation of automated GIS tools for delineating karst sinkholes and closed depressions from 1-meter LiDAR-derived digital elevation data. 13th Sinkhole Conference: 449-458.
Duggan DJ. 2014. Karst Prediction-Testing Predictions against Data, State of Qatar, MSc Thesis, University of Leeds, School of Geography, 181 p.

Eccleston BL, Pike JG, Harhash I. 1981. The Water Resources of Qatar and their Development: Water Resources and Agricultural Development Project (FAO Funds-in-Trust). Ministry of Industry and Agriculture, Government of The State of Qatar Technical Report 5 .

Embabi NS, Ali AA. 1990. Geomorphology of depressions in the Qatar Peninsula. Qatar University, Al-Ahleia Press, Doha: 357 p.

Haq BU, and Al-Qahtani AM. 2005. Jurassic-Neogene Arabian Platform Cycle Chart, in Phanerozoic cycles of sea-level change on the Arabian Platform. Gulf PetroLink, GeoArabia 10 (2): chart 1:2.

Howari FM, Aldouri R, Sadiq A. 2016. Gravity investigations of recent sinkholes and karst pits of Dahal Al-Hamam. State of Qatar Environmental Earth Sciences 5 (440): 10.

Kok CP, LeBlanc J. 2012. The Bir Zekreet Member, a new lithological unit (Member) of the Dammam Formation. Available from: https://drive.google. com/drive/folders/0B_FRE6vSR2MeMGwyaXdsNDVsdnM.

LeBlanc J. 2008. A fossil hunting guide to the Tertiary Formations of Qatar, Middle East. Available from: https://drive.google.com/drive/folders/0B FRE6vSR2MeMGwyaXdsNDVsdnM.

Orndorff RC, Weary DJ, Lagueux, KM. 2000. Geographic information systems analysis of geologic controls on the distribution of dolines in the Ozarks of south-central Missouri, USA. Acta Carsologica 29 (2): 161-175.

Perotti CR, Carruba S, Rinaldi M, Bertozzi G, Feltre L, Rahimi M. 2011. The Qatar-South Fars Arch Development (Arabian Platform, Persian Gulf): Insights from Seismic Interpretation and Analogue Modelling, in Schattner U. (ed.), New Frontiers in Tectonic Research - At the Midst of Plate Convergence, Dr. Uri Schattner (ed.): 325-352.

Sadiq AM, Nasir SJ. 2002. Middle Pleistocene karst evolution in the State of Qatar, Arabian Gulf. Journal of Cave and Karst Studies 64 (2): 132139.

Seltrust Engineering Limited. 1980. Explanatory Booklet to the Qatar Geologic Map (1:100,000 and 1:200,000 scale). Seltrust Engineering Limited, London, England, Industrial Development Technical Center, Doha, Qatar: 20.

Sharland PR, Casey DM, Davies RB, Simmons MD, Sutcliffe OE. 2004. Arabian Plate Sequence Stratigraphy - revisions to SP2. Gulf PetroLink, GeoArabia 9 (1): 199-212. 
U.S. Central Intelligence Agency. 2017. Middle East: Qatar. The World Fact Book: 9.

Weary DJ, Orndorff RC. 2002. Physical controls on karst features in the Ozark Plateaus of Missouri, USA, as determined by multivariate analyses in a geographic information system (GIS). Acta Carsologica 30 (2): 181-194.

Williams AH, Walkden GM. 2002. Late Quaternary highstand deposits of the southern Arabian Gulf: a record of sea-level and climate change, in Clift PD, Kroon D, Gaedicke C, Craig J (eds). The Tectonic and Climatic Evolution of the Arabian Sea Region. Geological Society of London Special Publication 195: 371-386.

Zampetti V, Marquez X, Mukund S, Bach S, Emang M. 2014. 3D seismic characterization of UER karst, offshore Qatar. International Petroleum Technology Conference IPTC 2014. 
